\title{
Comparative Yield Potential of Various Pleurotus spp./ Strains of Himachal Pradesh using Wheat Straw as Substrate
}

\author{
Rishu Sharma* and B.M. Sharma \\ CSKHPKV, Palampur, H. P- 176062, India \\ Corresponding author
}

\author{
A B S T R A C T
}

\begin{abstract}
Keywords
Pleurotus, Spawn run, Pinning initiation, Wheat straw, Substrate

Article Info

Accepted:

17 June 2018

Available Online:

10 July 2018

A total of 21 isolates of Pleurotus were procured/ collected from different sources, for conducting studies on yield potential using wheat straw as substrate. The species of genus Pleurotus show great diversity in their adaptation to varying agro-climatic conditions. Various species/strains of Pleurotus were collected/procured from different sources. Majority of the species/strains were collected from the natural habitat during surveys conducted in different localities of Himachal Pradesh during monsoon months of the year. Some of the species were procured from NRCM Solan. Isolations from the fresh specimen, collected from the wild were made following the standard tissue culture technique. Experimental fruiting of 21 isolates under mushroom house conditions revealed that the spawn run (11.6 days) and pinning initiation (16.6 days) was quick in Pleurotus sp. III followed by $P$. sapidus and Pleurotus sp. I. Maximum biological efficiency of 92 per cent was recorded in P. flabellatus I on the basis of two flushes.
\end{abstract}

\section{Introduction}

Pleurotus species constitute one of the choicest edible mushrooms, known by several names all over the world as 'Hiratake', 'Shimaji' or 'Houbitake' (Mizuno and Zhuang, 1995; Bononi et al., 1995). However, it is commonly known as 'Oyster Mushroom' and in India recognized by the name 'Dhingri Mushroom'. The species of Pleurotus are generally saprophytic and wood destroying fungi attacking both cellulose and lignin components of wood and are widespread in the temperate zones of the world (Zadrazil and Kurtzman, 1984). The species of Pleurotus grow wild in the forests of hilly areas and cultivated in temperate and sub-tropical regions of the world. These mushrooms are grown on unfermented cereal straws with good productivity. Oyster mushroom is well known for its culinary properties and broad adaptability under varied agro-climatic conditions. In terms of total world production of mushrooms in 2005 which is 5 million tons, Pleurotus constitutes 25 per cent and ranks second among the cultivated mushrooms (Anonymous, 2007). In 1997, Pleurotus production in world was reported to be 875,600 tons contributing 14.2 per cent to the total world mushroom production. Representatives of genus Pleurotus form a heterogeneous group of edible species of high 
commercial importance (Zervakis et al., 2004). The species of genus Pleurotus show great diversity in their adaptation to the varying agro-climatic conditions. This flexible nature of the genus gives it more importance than any other cultivated mushroom (Zadrazil and Dube, 1992). Pleurotus spp. cultivation was first started in the $19^{\text {th }}$ century on tree stumps (Flack, 1917). In India, Pleurotus cultivation was standardized by Bano and Srivastava (1962) utilizing $P$. flabellatus and the first domesticated species was $P$. ostreatus. Later, P. sajor-caju gained much importance after Jandaik and Kapoor (1974) first reported its cultivation on banana pseudo stem and chopped paddy straw. Different substrates have been used by several workers for the cultivation of Pleurotus spp. viz. cotton waste (Chang et al., 1981), jowar straw and groundnut pod (Khandar et al., 1991), wheat straw (Gupta and Langer, 1988), rubber wood waste (Mathew et al, 1991). Thomas et al., (1998) have reported rice straw, as the most widely used substrate in Asia for the cultivation of Pleurotus spp. Mendeel et al., (2005) used cardboard, saw dust and plant fibres for the cultivation of Pleurotus spp. Similarly Mendez et al., (2005) utilized maize and pumpkin straw as substrates. Several diverse substrates like lignocellulosic materials (Yildiz et al., 2002), unpretreated spent beer grains (Wang et al., 2001), banana and rice straw (Bonatti et al., 2004), various dry weed plants (Das and Mukherjee, 2007), peat moss based substrate (Tawiah and Martin, 2006) have also been used for the cultivation of $P$. ostreatus. Silva et al., (2002) have used cotton peel as substrate for $P$. pulmonarius. Wheat bran supplemented with umbrella plant was used for cultivation of $P$. eryngii (Ohga and Royse, 2004). Thus, the present study was carried out with the objective to determine the high yielding Pleurotus spp. using wheat straw as a substrate. Also, it was planned to determine which Pleurotus spp took minimum and maximum days for spawn run, pinning initiation and biological efficiency.

\section{Materials and Methods}

\section{i) Collection, isolation and maintenance of pure culture}

Various species/strains of Pleurotus were collected/procured from different sources. Majority of the species/strains were collected from the natural habitat during surveys conducted in different localities of Himachal Pradesh during monsoon months of the year. Some of the species were procured from NRCM Solan (Table 1). Isolations from the fresh specimen, collected from the wild were made following the standard tissue culture technique (Gomborg, 2002). Young and fresh specimens were first washed with a jet of sterile water and cut across the pileal region with the help of a sterilized sharp blade to get 2-3 mm bits. These bits were dipped in 0.1 per cent Mercuric chloride solution with the help of sterilized forceps for 5-10 seconds and were given five washings in sterilized distilled water and placed on sterilized filter paper to remove excess moisture. The sterilized bits were then transferred to Yeastal Potato Dextrose Agar medium slants and incubated at $22 \pm 2{ }^{\circ} \mathrm{C}$. The stock cultures were maintained in the refrigerator at $4^{\circ} \mathrm{C}$. Sub-culturing of the stock cultures was done after a period of 7-10 days on fresh YPDA slants.

\section{ii) Preparation of spawn}

Wheat grains were sieved for the removal of undesirable materials and given 2-3 washings with water in a wide mouth container. The grains were then boiled in water for 15 minutes and soaked in hot water for 12-15 minutes. Water was decanted and the grains were spread on a wire-mesh for 7-8 hours for surface drying of grains. $18.0 \mathrm{~g}$ gypsum and $6.0 \mathrm{~g}$ calcium carbonate were added to one $\mathrm{kg}$ 
of wheat grains. 300 gms of boiled grains were filled in glucose bottles upto two third of the total volume, plugged with non-absorbent cotton and autoclaved at $22 \mathrm{lbs}$ p.s.i. pressure at $126^{\circ} \mathrm{C}$ for 1.5 hours. Sterilized bottles were kept in the room for 24 hours to remove the excess moisture. The bottles were then kept for overnight cooling in room, under the UV light for 30 minutes. A $5 \mathrm{~mm}$ mycelial bit from fresh culture was transferred aseptically to one side of the bottle and another bit to the other side of the bottle and kept at $22 \pm 2^{\circ} \mathrm{C}$. Incubated bottles were shaken weekly until there was a complete mycelial colonization of wheat grains. Fully colonized spawn bottles were then used for spawning of the bags.

\section{iii) Spawning}

For conducting fruiting trials of various species/strains, cloth bags were filled with 250 gms of wheat straw. The bags were dipped in water overnight and were pasteurized in hot water at $65-70^{\circ} \mathrm{C}$ for 6 hours and then boiled in a drum for 1.5 to 2 hours. Wheat straw was cooled after spreading on a sterilized polythene sheet and tightly filled in polypropylene bags having small holes for aeration. Layer spawning was done and the bags were tied at the top and properly labelled.
Spawned bags were kept in the mushroom house (Temperature $22 \pm 2^{\circ} \mathrm{C}$ and relative humidity $80-85 \%$ ) for spawn run. After complete spawn run, the bags were torn opened and hanged with the help of plastic rope on an iron frame for fruiting. The data on spawn run, pinning initiation, fruiting behaviour and yield pertaining to various isolates were recorded.

\section{Results and Discussion}

A total of 21 isolates were collected /procured from different sources to have a fairly large sample size for determining the yield attributes and potential of each collected sample on wheat straw. Experimental fruiting of 21 isolates under mushroom house conditions revealed that the spawn run (11.6 days) and pinning initiation (16.6 days) was faster in Pleurotus sp. III followed by $P$. sapidus and Pleurotus sp. I (Table 2). Varying period of spawn run and pinning initiation has been reported for various species on different substrates by several workers from time to time (Baysal et al., 2003). All the 21 isolates of Pleurotus were evaluated for their spawning behaviour following the standard technique (Munjal, 1973).

Table.2 Comparative yield potential of various Pleurotus species / strains on wheat straw

\begin{tabular}{clcccc}
\hline $\begin{array}{c}\text { S. } \\
\text { No }\end{array}$ & SPECIES / STRAINS & $\begin{array}{c}\text { SPAWN RUN } \\
\text { (DAYS) }\end{array}$ & $\begin{array}{c}\text { PINNING } \\
\text { INITIATION } \\
\text { (DAYS) }\end{array}$ & $\begin{array}{c}\text { YIELD (g/250g } \\
\text { dry substrate) }\end{array}$ & $\begin{array}{c}\text { BIOLOGICAL } \\
\text { EFFICIENCY (\%) }\end{array}$ \\
\hline 1. & Pleurotus eryngii I & 13.3 & 17.3 & 200.0 & 80.0 \\
2. & Pleurotus sapidus & 12.6 & 16.6 & 205.0 & 82.0 \\
3. & Pleurotus sp.I & 12.6 & 16.3 & 214.1 & 85.6 \\
4. & Pleurotus florida & 14.6 & 18.3 & 218.3 & 87.3 \\
5. & Pleurotus flabellatus II & 16.6 & 20.6 & 220.8 & 88.3 \\
6. & Pleurotus ostreatus IV & 14.6 & 17.6 & 190.8 & 76.3 \\
7. & Pleurotus flabellatus I & 14.3 & 19.6 & 230.0 & 92.0 \\
8. & Pleurotus sp.II & 16.3 & 21.3 & 107.5 & 43.0 \\
9. & Pleurotus ostreatus III & 14.3 & 18.3 & 211.6 & 84.6 \\
10. & Pleurotus cornucopiae & 16.3 & 20.6 & 227.5 & 91.0 \\
11. & Pleurotus eryngii II & 14.6 & 18.6 & 226.6 & 90.6 \\
12. & Pleurotus sp.III & 11.6 & 16.6 & 225.8 & 90.3 \\
& C.D (5\%) & $\mathbf{0 . 9 7}$ & $\mathbf{0 . 9 7}$ & $\mathbf{5 . 9 9}$ & $\mathbf{2 . 3 9}$ \\
\hline
\end{tabular}


Table.1 Source of collection of various Pleurotus species/strains

\begin{tabular}{|c|c|c|}
\hline SOURCE & NAME & SPECIES /STRAINS \\
\hline Collection from wild & $\begin{array}{l}\text { P11 } \\
\text { P5 } \\
\text { P21 } \\
\text { P3 } \\
\text { P4 } \\
\text { P12 } \\
\text { P6 } \\
\text { P8 } \\
\text { P10 } \\
\text { P18 } \\
\text { P19 } \\
\text { P20 } \\
\text { P7 } \\
\text { P15 } \\
\text { P17 }\end{array}$ & $\begin{array}{l}\text { Pleurotus sp.II } \\
\text { Pleurotus cystidiosus I } \\
\text { Pleurotus ostreatus IV } \\
\text { Pleurotus flabellatus II } \\
\text { Pleurotus cornucopiae } \\
\text { Pleurotus cystidiosus II } \\
\text { Pleurotus pulmonarius } \\
\text { Pleurotus fossulatus I } \\
\text { Pleurotus fossulatus II } \\
\text { Pleurotus sp.IV } \\
\text { Pleurotus sp.V } \\
\text { Pleurotus ostreatus III } \\
\text { Pleurotus sp.I } \\
\text { Pleurotus sp.III } \\
\text { Pleurotus eryngii II }\end{array}$ \\
\hline NRCM, Solan & $\begin{array}{l}\text { P1 } \\
\text { P2 } \\
\text { P9 } \\
\text { P13 } \\
\text { P14 } \\
\text { P16 }\end{array}$ & $\begin{array}{l}\text { Pleurotus sapidus } \\
\text { Pleurotus flabellatus I } \\
\text { Pleurotus florida } \\
\text { Pleurotus ostreatus I } \\
\text { Pleurotus eryngii I } \\
\text { Pleurotus ostreatus II }\end{array}$ \\
\hline
\end{tabular}

Fig.1 Various fructified isolates of Pleurotus spp. under the mushroom house conditions

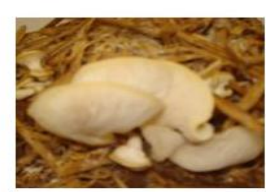

Pleurotus sp.II

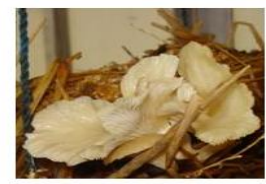

P.osteatus IV

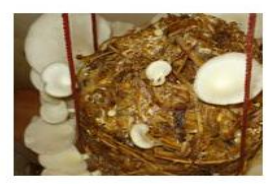

Pleurotus sp. I

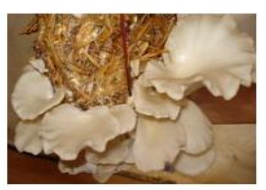

P. flabellatus II

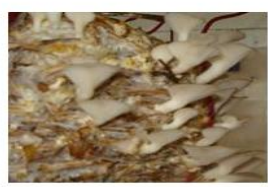

P.eryngii II

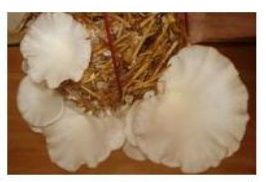

Pleurotus sp. II 
The experimental fruiting trials were conducted under the mushroom house conditions. However, among 21 isolates only twelve showed fructification (Fig. 1). The fruiting trials were observed to note the various attributes. It was observed that the spawn run (11.6 days) and pinning initiation (16.6 days) was quick in Pleurotus sp. III followed by P. sapidus and Pleurotus sp. I. Maximum biological efficiency of 92 per cent was recorded in P. flabellatus I on the basis of two flushes. Mendeel et al., (2005) evaluated the biological efficiency of three Pleurotus species namely $P$. columbinus, $P$. sajor-caju and $P$. ostreatus on organic wastes, reported a maximum biological efficiency $(134.5 \%)$ in $P$. columbinus on cardboard. Similarly, we also got a higher biological efficiency of $91 \%$ in $P$. cornucopiae. Though, further studies are required to ascertain the best substrate using the different substrates for the cultivation of Pleurotus spp./strains.

\section{Acknowledgement}

Authors are grateful to National Horticultural Board for the financial assistance and Department of Plant Pathology, CSHPKV, Palampur, Himachal Pradesh for cooperating us in conducting this experiment

\section{References}

Anonymous (2007). Mushroom Production Baysal, E., Pecker, H., Yalinkilic, M. F. and Temiz, A (2003). Cultivation of oyster mushroom on waste paper with some added supplementary materials. Bioresource Technology 89(1): 95-97.

Bonatti, M., Karnopp, P., Soares, H.M. and Furlan, S. A (2004). Evaluation of Pleurotus ostreatus and Pleurotus sajor-caju nutritional characteristics when cultivated in different lignocellulosic wastes. Food Chemistry 88(3): 425-428.
Bano, Z. and Srivastava, H.C (1962). Studies on the cultivation of Pleurotus species on paddy straw. Food Science 11: 3638

Bononi, V.L.; Capelari, M.; Maziero, R.; Trufem, S.F.B (1995). Cultivo de cogumelos comestíveis São Paulo: Ícone,. pp. 206.

Chang, S.T., Lau, O.W. and Cho, K.Y (1981). The cultivation and nutritional value of Pleurotus sajor-caju. European Journal of Applied Microbiology and Biotechnology 12: 58-62.

Das, N. and Mukherjee, M (2007). Cultivation of Pleurotus ostreatus on weed plants. Bioresource Technology 98(14) ; 2723-2726.

Flack, R (1917). Uber die waldknuttur des Austernpilzes (Agaricus ostreatus). Auf Laudhozstubben. Zeitschrift for furstundiagdwesen, 49: 159-165

Gupta, V.K. and Langer, P.N (1988) Pleurotus florida for upgrading the nutritive value of wheat straw. Biological wastes 23: 57-64

Gamborg, O.L. (2002) Plant tissue culture. Biotechnology. Milestones. In Vitro Cellular \& Developmental Biology. 38(2): 84-92.

Jandaik, C. L. and Kapoor, J. N.(1974) Studies on cultivation of Pleurotus sajor-caju. Mushroom Science 9(1): 667-672.

Khandar, R.R., Vaishnav, M.V., Akbari, L.F. and Andhania, J.H (1991). Effect of various plant substrates on sporophore production of Pleurotus sajor-caju. Indian Mushrooms. Proceedings National Symposium on Mushrooms, Thiruvananthpuram, pp. 287-288.

Mathew, J.R., Kothandaraman and Thresiama, K.J(1991). Cultivation of oyster mushrooms on rubber processing factory waste- a possible solid waste utilization method. Indian Mushrooms Proceedings National 
Symposium on Mushrooms (1991). Thiruvananthpuram. pp. 97-99.

Mendeel, Q.A., Loith, A.A. and Mohamed, S.A (2005). Cultivation of oyster mushrooms (Pleurotus spp.) on various lignocellulosic wastes. World Journal of Microbiology and Biotechnology 21: 601-607.

Mizuno, T. and Zhuang, C (1995). Pleurotus sajor-caju antitumor-activity and utilization. Food Reviews International 11. pp.185-187

Munjal, R.L (1973). Production of quality spawn of Agaricus bisporus and Volvariella spp. Indian Journal of Mushroom 1(1): 1-4.

Ohga, S. and Royse, D (2004). Cultivation of Pleurotus eryngii on umbrella plant (Cyperus alternifolius) substrate. Journal of Wood Science 50(5): 466469.

Silva, S.O., Costa, S.M.G. and Clemente, E (2002). Chemical composition of Pleurotus pulmonarius(Fr.) Quel., substrates and residue after cultivation. Brazilian Archives of Biology and Technology 45(4): 531535

Tawiah, W.M. and Martin, A.M (2006). Cultivation of Pleurotus ostreatus mushroom in peat. Journal of the Science of Food and Agriculture 37(9): 833-838.

Thomas, G.V., Prabhu, S.R., Reeny, M.Z. and
Bopaiah, B.M (1998). Evaluation of lignocellulosic biomass from coconut palm as substrate for cultivation of Pleurotus sajor-caju. (Fr.) Singer. World Journal of Microbiology and Biotechnology 14: 879-882.

Wang, D., Sakoda, A. and Suzuki, M (2001). Biological efficiency and nutritional value of Pleurotus ostreatus cultivation on spent beer grain. Bioresource Technology 78 (3): 293300.

Yildiz, S., Yildiz, U.C., Gezer, E.D. and Temiz, A (2002) Some lignocellulosic wastes used as raw materials in cultivation of the Pleurotus ostreatus culture mushroom. Process Biochemistry 38 (3): 301-306.

Zardazil, F. and Kurtzman, Jr. R. H (1984). The biology of Pleurotus cultivation in the tropics. In Tropical Mushrooms, (Eds. S. T. Chang and T.H. Quimio), The Chinese University Press, HongKong pp. 227-298.

Zervakis, G. I., Monslavo, J. M. and Vilgalys, $\mathrm{R}$ (2004). Molecular phylogeny, biogeography and speciation of the mushroom species Pleurotus cystidiosus and allied taxa. Microbiology 150: 715-726.

Zadrazil, F. and Dube, H.C (1992). The oyster mushroom importance and prospects. Mushroom Research 1(1): 25-32.

\section{How to cite this article:}

Rishu Sharma and Sharma, B.M. 2018. Comparative Yield Potential of Various Pleurotus spp./ Strains of Himachal Pradesh using Wheat Straw as Substrate Int.J.Curr.Microbiol.App.Sci. 7(07): 2155-2160. doi: https://doi.org/10.20546/ijcmas.2018.707.254 